BRENT M. DAVIS ${ }^{1}$

AZUSA PACIFIC UNIVERSITY

DePARTMENT OF GLOBAL STUdies,

SOCIOLOGY AND TESOL

\title{
ADDRESSING GRAMMAR IN THE INTERACTION TASK-BASED LEARNING ENVIRONMENT
}

ABSTRACT. One of the major problems in language teaching is developing grammatical accuracy. This paper proposes that using error correction based on a functional grammar in a task-based learning approach may be a suitable solution. Towards this end an emic (using categories intrinsic to the language) functional grammar of the verb phrase is proposed and a description of how this fits into the focus on form component of task-based learning is provided.

KEY WORDS: error correction, functional grammar, task-based learning.

1 bredav2@hotmail.com

This paper was submitted on August 15, 2017 and accepted for publication at the meeting of the Editorial Board held on September 19, 2017. 


\section{INTRODUCTION: THE ROLE OF GRAMMAR IN A COMMUNICATIVE SYLLABUS}

One of the enduring questions in syllabi which are not primarily based on grammar is how (and whether) does one teach grammar in the syllabus. One answer, the Natural Approach (Krashen \& Terrell, 1983), simply allows the learner to develop grammar naturally as in first language learning. Unfortunately, second language learners rarely develop correct grammar naturally. Instead a pidgin is developed which more-or-less approximates native-speaker grammar (Swain, 2000). Particularly in writing for academic purposes a high level of grammatical accuracy is required and learners will need guidance on achieving this level of mastery of language form. Ellis $(2005$, p. 13) lists the possible approaches to learning grammar as: Explicit (either deductive or inductive), implicit (as in the Natural Approach), structured input, production practice, or corrective feedback. A similar listing can be found in Lightbown and Spada (cited in Willis and Willis, 2007) call the main approaches "get it right in the beginning" and "get it right in the end." With the former representing traditional approaches and showing generally poor results.

Larsen-Freeman (2001) notes three components of a grammatical structure: form, meaning, and usage. Traditional teaching focuses on form and often provides little or no guidance on meaning or usage. The Interaction approach naturally begins with usage and the question is how to incorporate form and meaning (Davis, 2016). According to Ellis (2005, p. 16), the best instruction is based on function, and there is disagreement about the effectiveness of corrective feedback (which is often a component of the "get it right in the end" approach (Willis \& Willis, 2007) [section 6.5.2]).

The answer of task-based learning is to invert the traditional order of form to meaning and go from meaning to form. In this paper, I will discuss the issue of improving form in the task-based learning approach with an emphasis on English for Academic Purposes (EAP). 


\section{FORM FOCUS}

Task-based learning has three phases: vocabulary introduction, meaning-focused tasks, and focus on form (Willis \& Willis, 2007) (Ellis, 2005). As noted above, functional instruction has been shown to be effective, but we need to consider how it can be incorporated into the focus on form phase. Since this phase is at the end of the task-based learning cycle, there has already been some form input. Since the preceding task phase would be likely to generate formal errors as the learners negotiate meaning, there would be some forms which need correction. Later, let us also consider the bridge from form to function to traditional grammar (which is needed for most composition courses that follow EAP writing courses). Error correction and functional grammar will be connected by appropriate activities which will also be examined later.

\section{FUNCTIONAL GRAMMAR}

Every grammatical form has one or more functions. Halliday's grammar (Halliday \& Matthiessen, 2004) provides useful functional labels to begin our task of assigning function to form. Another approach is tagmemics which provides a more emic (Franklin, 1996) approach to grammar which should facilitate noticing and avoid the disjointed and perhaps confusing categories of traditional grammar by instead placing all functional uses of a form in one category. An emic approach gives more of an insider approach.

\section{INTEGRATING FOCUS ON FORM AND FOCUS ON FORMS THROUGH FUNCTION}

The goal of grammar instruction is to enable the production of acceptable forms and the ability to edit errors on one's own. Rod Ellis (citing Long) (Ellis, 2005, p. 12) notes the distinction between focus on forms in traditional instruction and focus on form in task-based learning. Focus on forms approaches have been criticized for not producing adequate results in enabling learners to produce acceptable forms. Focus on form should be emphasized 
over focus on forms and is situated in analyzing meaningful texts related to the task. An example would be a cloze activity based on a text (Willis \& Willis, 2007) [section 3.5 of Kindle version]. Particularly in English for Academic Purposes there is eventually a need to connect a focus on form with a more traditional focus on forms. This process could be logically set out as 1) generate forms in meaningful contexts, 2) correct forms, 3) link correction to textual function, and 4) connect forms and functions to traditional grammatical labels (which knowledge will be needed for testing and processing feedback on composition assignments after EAP). This study focuses on verb phrases which, in my experience, is a particular area of difficulty for second-language learners.

Halliday and Matthiessen (2004, p. 336) point out the functional structure of the verb phrase: the beginning of the phrase situates the event in the here and now while the end of the phrase gives the new, representational information. Thus, we encounter tense (finiteness) at the beginning and the main action at the end. In the middle, we encounter what I take to be the standpoint of the speaker to the event. From my analysis, there are up to three different types of situating functions which occur in certain sequences and permit limited repetition in theory for the medial functions. The functions are set out below in a table, but are first, as noted by Halliday and Matthiessen, the finite (tensed) bearing verb, this in the simplest patterns is fused with the representational (primary action) verb. For example: He ate. Second, we may find that the subject is linked to something (using the verb 'be') or desituated (using the verb 'have + completed aspect'). Third, a verb may establish a relation with another verb using the infinitive or incomplete aspect such as a cognitive state, a phase in execution or a purpose. The tense and modal functions can only occur once and must be the first forms in a verb phrase. Combinations of other forms may follow leading to one [barring coordination with 'and'] verb expressing the main action/event. For example: "he has been trying to finish buying the book," functionally [desituated] [link to incomplete action state] [status] [status] [primary action].

I tried out a form to function approach with a small (4 learners) class of adults, and was encouraged by the results. These were high beginners, but they seemed to grasp the categories and produce more accurate sentences than similar students I have taught using a traditional grammar book such as Azar's (2011). It should be 
noted that at least one student had previous notes using a more traditional approach.

The basic patterns I used were built around three main verbs: do, be, and have. These forms can all serve as the tensed verbs in questions, negatives and certain positive statements and thus represent three important forms that need to be mastered. For example: Do you eat spinach? I don't eat spinach. She does eat spinach. Are you eating spinach? I am not eating spinach. She is eating spinach. Have you eaten spinach? I have not eaten spinach? She has eaten spinach. The only other verbs that can take these slots are modals like can and might. The term slot was used for early slot and filler grammars which are perhaps best represented by Pike's tagmemic approach. Tagmemics connects categories with functions which suits the purposes of this study.

Here is an updated version of the functional categories taught to the students (Table 1$)^{2}$

In my pilot course, the students were given several sentences on strips of paper and asked to categorize them. Many of these sentences had been introduced in previous tasks (dialogues about family and interests). Initially, they mainly sorted them into questions and statements, but when asked to specifically sort by verb (do, be, have) they were able to do so easily. Let us consider how this task could be improved to meet the goal of focus on form through error correction.

\section{THE VALUE OF GROUP WORK}

Ellis (2005, p. 22) notes the potential advantages of group work. This is particularly true when dealing with adult learners (Vella, 2002). A group task for correcting form and function would be more effective than a more teacher-centered one. Interaction task-based learning (Davis, 2016) focuses on tasks relevant to interactions in the community and other social institutions. Thus, I could have had the learners write out their own dialogues (or for more advanced learners original paragraphs). This would have generated some errors which could be addressed and they would have occurred in meaningful tasks (see Willis, section 1.5). Next, the students could

2 Certain labels have been refined after further reflection and only the first two functions were addressed due to the low level of the students. 


\begin{tabular}{|c|c|c|c|c|c|}
\hline TAGMEME & $\begin{array}{l}\text { \{time/immedi- } \\
\text { acy\} } \\
\text { certitude/ad- } \\
\text { visability/pos- } \\
\text { sibility }\end{array}$ & $\begin{array}{l}\text { active/stative/ } \\
\text { experiential }\end{array}$ & aspect & $\begin{array}{l}\text { cognitive/se- } \\
\text { quential/pur- } \\
\text { posive }\end{array}$ & main action \\
\hline FORM & $\begin{array}{l}\text { will/should/ } \\
\text { can }\end{array}$ & do/be/have & -ed/-ing/to & like/begin/etc. & eat/go/etc. \\
\hline 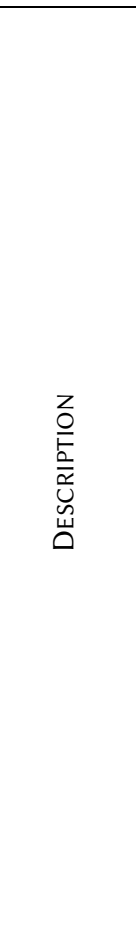 & $\begin{array}{l}\text { These func- } \\
\text { tions are well } \\
\text { established for } \\
\text { the modal cate- } \\
\text { gory. Note that } \\
\text { tense always } \\
\text { attaches to the } \\
\text { first form in a } \\
\text { verb phrase } \\
\text { which is either } \\
\text { a modal or a } \\
\text { main verb. }\end{array}$ & $\begin{array}{l}\text { Aside from } \\
\text { modals the } \\
\text { main tensed } \\
\text { verbs in ques- } \\
\text { tions and nega- } \\
\text { tivestatements } \\
\text { are do/be and } \\
\text { have which } \\
\text { seem to ex- } \\
\text { press situated } \\
\text { action, linked } \\
\text { states and (un- } \\
\text { situated) expe- } \\
\text { riences respec- } \\
\text { tively. Linked } \\
\text { states may in- } \\
\text { clude non-ver- } \\
\text { bal comple- } \\
\text { ments such as } \\
\text { noun phrases, } \\
\text { adjectives, par- } \\
\text { ticipial phrases } \\
\text { and dependent } \\
\text { clauses. }\end{array}$ & $\begin{array}{l}\text { Following an } \\
\text { action or do/ } \\
\text { be/have we } \\
\text { may have a } \\
\text { participle } \\
\text { showing aspect } \\
\text { (perfective or } \\
\text { imperfective) } \\
\text { or the un- } \\
\text { marked infini- } \\
\text { tive }\end{array}$ & $\begin{array}{l}\text { Where there } \\
\text { are two verb } \\
\text { sequences } \\
\text { (particularly } \\
\text { where the sec- } \\
\text { ond one is an } \\
\text { infinitive) the } \\
\text { first verb indi- } \\
\text { cates the status } \\
\text { of the second } \\
\text { verb, usually a } \\
\text { cognitive rela- } \\
\text { tion (like, } \\
\text { want, need), } \\
\text { point in a se- } \\
\text { quence (begin, } \\
\text { continue, } \\
\text { stop), or pur- } \\
\text { pose. }\end{array}$ & $\begin{array}{l}\text { Finally, the last } \\
\text { verb in a verb } \\
\text { phrase carries } \\
\text { the primary se- } \\
\text { mantic load } \\
\text { such as eat, go, } \\
\text { study. } \\
\text { An adverb may } \\
\text { follow this as } \\
\text { well. }\end{array}$ \\
\hline 売 & $\begin{array}{l}\text { Will you go? I } \\
\text { won't go. } \\
\text { Should I go? } \\
\text { Can he go? }\end{array}$ & $\begin{array}{l}\text { This is a book. } \\
\text { This is good. } \\
\text { This is on top. } \\
\text { This is what I } \\
\text { mean. } \\
\text { Have you read } \\
\text { this book? I ha- } \\
\text { ven't read it. }\end{array}$ & $\begin{array}{l}\text { It is finished. It } \\
\text { is finishing. }\end{array}$ & $\begin{array}{l}\text { He wanted to } \\
\text { get the book. } \\
\text { He began to get } \\
\text { the book. He } \\
\text { ran to get the } \\
\text { book. }\end{array}$ & $\begin{array}{l}\text { He eats. He is } \\
\text { eating. He has } \\
\text { eaten. He } \\
\text { needs to eat. }\end{array}$ \\
\hline
\end{tabular}

TABLE 1

have been put into groups or pairs and given one (to avoid overwhelming the learners) function to identify with its relevant form. This would necessitate the teacher going through the task in advance and identifying that that particular form problem did in fact occur. The learners would then locate the error and correct it. 
Thus, the goal is to provide focus on form activities that provide effective error correction, an understanding of grammatical functions from an emic standpoint, and a basis for a transition to more traditional grammatical labels. The transition would be done in advanced writing courses.

CONCLUSION This paper sets forth an approach to learning grammar through activities focusing on correcting errors by using a functional grammar in the focus on form phase of task-based learning. This approach, particularly when combined with group activities should lead to better results over teacher centered, traditional, explicit grammar rule explanation. One of the novel features presented is a unique, emic functional grammar of the verb phrase which seeks to understand English forms in sets of similar forms. This approach also has the advantage of not distributing similar forms over different grammatical functions such as discussing 'be' plus completed action as passive, but 'be' plus incomplete action as continuous which should be less confusing to the learner. A small pilot class was promising, but further research is needed to provide empirical evidence for this approach, although various incorporated elements are based on previous research.

REFERENCES

Azar, B. S. (2011). Fundamentals of English Grammar (4th ed.). Boston, MA: Pearson ELT.

Davis, B. (2016). A Communicative-Competence Syllabus Organized According to Social Institutions. In: Nataša Bakić-Mirić (Ed.), Going Forward: Recent Developments in Higher Education (pp. 31-46). Newcastle-on-Tyne: Cambridge Scholars Publishing.

Ellis, R. (2005). Instructed Second Language Acquisition: A Literature Review. Auckland: New Zealand Ministry of Education.

Franklin, K. J. (1996, November 27). K. L. Pike on Etic vs. Emic: A Review and Interview. Retrieved from SIL.org: http://www-01.sil.org/klp/karlintv.htm

Halliday, M. A., \& Matthiessen, C. M. (2004). An Introduction to Functional Grammar (3rd ed.). London: Hodder Arnold. Retrieved July 17, 2017, from http:// www.uel.br/projetos/ppcat/pages/arquivos/RESOURCES/2004_HALLIDAY_MATTHIESSEN_An_Introduction_to_Functional_Grammar.pdf

Krashen, S. D., \& Terrell, T. D. (1983). The Natural Approach. New York: Alemany Press. 
Larsen-Freeman, D. (2001). Teaching Grammar. In: M. Celce-Murcia (Ed.), Teaching English as a Second or Foreign Language (pp. 251-266). Boston: Heinle \& Heinle.

Swain, M. (2000). The Output Hypothesis and Beyond: Mediating Acquisition through Collaborative Dialogue. In: J. P. Lantolf (Ed.), Sociocultural Theory and Second Language Learning (pp. 97-114). Oxford: OUP.

Vella, J. (2002). Learning to Listen, Learning to Teach: The Power of Dialogue in Educating Adults. San Francisco: Jossey-Bass.

Willis, D., \& Willis, J. (2007). Doing Task-based Teaching. Oxford: OUP.

БРЕНТ М. ДЕЈВИС

УНИВЕРЗИТЕТ АЗУСА ПАСИФИК

ДЕПАРТМАН ЗА ОПШТЕ СТУДИЈЕ, СОЦИОЛОГИЈУ И

ЕНГЛЕСКИ КАО СТРАНИ ЈЕЗИК

РЕЗИМЕ

ГРАМАТИКА У ИНТЕРАКТИВНОМ ОКРУЖЕЊУ УЧЕњА ЗАСНОВАНОГ НА ЗАДАТКУ

Један од већих проблема у настави језика јесте развијање граматичке исправности. Овај рад предлаже као адекватно решење употребу технике исправљања грешака на основу функционалне граматике код приступа заснованог на задатку. Сходно наведеном, предлаже се етіс (употреба категорија интринзичних језику) функционална граматика глаголске синтагме као и описивање начина на који се ово уклапа у фокусирање на компоненту облика учења заснованог на задатку.

КљУчнЕ РЕчи: учење засновано на задатку, функционална граматика, исправљање грешака.

Овај чланак је објављен и дистрибуира се под лиценцом Creative Commons Ауторство-Некомерцијално Међународна 4.0 (CC BY-NC 4.0 |

https://creativecommons.org/licenses/by-nc/4.0/).

This paper is published and distributed under the terms and conditions of the Creative Commons Attribution-NonCommercial International 4.0 licence (CC BY-NC 4.0 | https://creativecommons.org/licenses/by-nc/4.0/). 